\title{
Post-Chernobyl surveys of radiocaesium in soil, vegetation, wildlife and fungi in Great Britain
}

\author{
J. S. Chaplow, N. A. Beresford, and C. L. Barnett \\ Centre for Ecology \& Hydrology, Lancaster Environment Centre, Library Avenue, Bailrigg, Lancaster, \\ Lancashire, LA1 4AP, UK \\ Correspondence to: J. S. Chaplow (jgar@ceh.ac.uk)
}

Received: 3 October 2014 - Published in Earth Syst. Sci. Data Discuss.: 5 December 2014

Revised: 29 July 2015 - Accepted: 3 August 2015 - Published: 20 August 2015

\begin{abstract}
The data set "Post Chernobyl surveys of radiocaesium in soil, vegetation, wildlife and fungi in Great Britain" was developed to enable data collected by the Natural Environment Research Council after the Chernobyl accident to be made publicly available. Data for samples collected between May 1986 (immediately after Chernobyl) to spring 1997 are presented. Additional data to radiocaesium concentrations are presented where available. The data have value in trying to assess the contribution of new sources of radiocaesium in the environment, providing baseline data for future planned releases and to aid the development and testing of models.

The data are freely available for non-commercial use under Open Government Licence terms and conditions. doi:10.5285/d0a6a8bf-68f0-4935-8b43-4e597c3bf251. Supporting information to assist with the reuse of this data is available from the Environmental Information Data Centre (EIDC) (http://eidc.ceh.ac.uk/).
\end{abstract}

\section{Background}

The accident at the Chernobyl Nuclear Power Plant (Ukraine) on 26 April 1986 remains the worst accident in nuclear history (Smith and Beresford, 2005). The explosion released large quantities of radioactivity into the atmosphere, which spread over much of western Union of Soviet Socialist Republics (USSR) and Europe (De Cort et al., 1998).

The radioactive plume reached the United Kingdom on 2 May 1986 (Smith and Clark, 1989), with relatively high levels of deposition being recorded in areas which received heavy rainfall during the passage of clouds over the country (Allen, 1986; Smith and Clark, 1989). Areas receiving high levels of deposition tended to be upland areas in the west. The grazing of free-ranging sheep is the predominant land use in many of these areas which are characterised by nutrient-poor, highly organic acidic soils (Beresford et al., 2007). This resulted in radiocaesium in the tissues of sheep that exceeded $1000 \mathrm{~Bq} \mathrm{~kg}^{-1}$ fresh weight, the limit adopted within the UK after Chernobyl to designate meat that could not enter the food chain. Consequently, in 1986 restrictions were placed on the movement and slaughter of animals from 1670 farms in west Cumbria (north-west England), 5100 farms in north Wales and 2144 farms in Scotland. Subsequently, 122 farms in Northern Ireland were placed under restriction in 1987. Whilst the number of farms under restriction reduced relatively rapidly, in 1991 more than 700 farms were still restricted, and restrictions were only finally lifted on the remaining 334 farms in Wales and 8 Cumbrian farms in June 2012 (26 years after the Chernobyl accident) (Environment Agency et al., 2013).

In May 1986 a survey of radiocaesium in vegetation was carried out (Horrill and Lindley, 1990) by the Institute of Terrestrial Ecology (ITE) (the predecessor of the Centre for Ecology \& Hydrology (CEH)). Samples were collected from 318 sampling sites which were selected to represent 16 different land classes (described below). This was used to produce the first map of contamination across Great Britain (Allen, 1986). Subsequently, some of these sites were resampled, with soil also being collected and analysed. Over the following years the institute conducted a number of surveys focussed on specific areas or to address questions of long-term management of the affected areas and particular routes of transfer to human consumers. Although a number of radionuclides were observed in the initial fallout in Great Britain (e.g. Howard and Beresford, 1989), the long-term fo- 
cus was on caesium-134 $\left({ }^{134} \mathrm{Cs}\right)$ and caesium-137 $\left({ }^{137} \mathrm{Cs}\right)$. The ${ }^{137} \mathrm{Cs}:{ }^{134} \mathrm{Cs}$ ratio from the Chernobyl deposition was ca. $2: 1$ in 1986 and hence the ratio could be used to distinguish aged Cs deposits (pre-Chernobyl) from Chernobyl derived Cs (see Beresford et al., 1992, for discussion).

Whilst the resultant data have been used for a number of purposes (e.g. development and testing of predictive models (Gillett et al., 2001; Wright et al., 2003), estimation of the intake of radiocaesium by consumers of wild fungi (Barnett et al., 1999), understanding of the behaviour of radiocaesium in upland farming systems (Beresford et al., 2007)) they have never been published in their entirety and in many instances not even summaries were made available in the open literature. In this paper we present a description of the postChernobyl data collected by ITE/CEH which have now been made openly available (Chaplow et al., 2015). The data have value in trying to assess the contribution of new sources of radiocaesium in the environment (e.g. as happened after the 2011 Fukushima accident; Beresford et al., 2012), providing baseline data for future planned releases (e.g. new nuclear power stations) and to aid the testing of models (e.g. the development of process-based models that require spatial data to enable their testing; Hinton et al., 2013). The purpose of this paper is to describe the available data and methodology used to obtain it. However, in instances where the data have not been reported previously in the open literature there is also a limited discussion of the results.

The research focused on caesium-137 which has a half-life of 30 years and was the most abundant and long lived component of the Chernobyl release. Other isotopes were measured in some samples.

\section{Data}

The data sets available from Chaplow et al. (2015) are the following:

1. Survey of Chernobyl fallout in graminaceous vegetation across Great Britain conducted in May and June 1986, and re-surveys carried out in October 1986 and spring 1987 (including samples of soil, different vegetation types and wild animals).

2. Survey of radiocaesium in vegetation sampled in Cumbria in 1986, north Wales in 1987, and North Yorkshire (north England) in 1988.

3. Survey of soil and vegetation over three sites in Cumbria conducted in 1989 and 1990.

4. Results of soil and vegetation sampling over the grazing areas of three upland sheep flocks in Cumbria conducted in 1992.

5. Survey of fungi and associated soil sampled from throughout Great Britain between autumn 1995 and spring 1998.

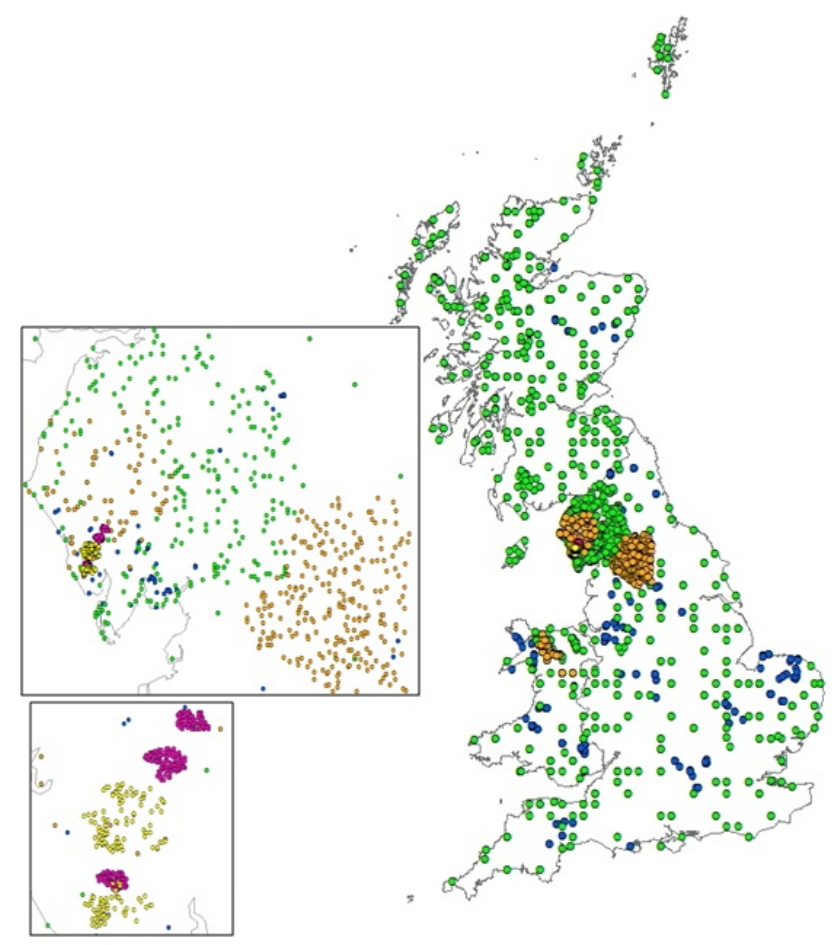

Figure 1. Location of sampling sites. Larger inset shows intensive sampling that was carried out in Cumbria and North Yorkshire; smaller inset shows sampling locations of Data sets 3 and 4 in Cumbria. Contains Ordnance Survey data ${ }^{\circledR}$ Crown Copyright and Database Right.

The above numbers are used in Table 1 and subsequently to identify the data sets. All the data are available as commaseparated variable files (Chaplow et al., 2015) and metadata are available as supporting information from the EIDC (http: //eidc.ceh.ac.uk/). Locations of sampling sites are presented in Fig. 1 and within the data as Latitude and Longitude.

\subsection{Overview of studies and available data}

\subsubsection{Data set 1}

To provide a rapid response for regulatory and scientific purposes to the deposition of Chernobyl-derived fallout, ITE conducted a survey of ${ }^{137} \mathrm{Cs}$ concentrations in grassy vegetation throughout mainland Great Britain in May-June 1986. The aim of the survey was to determine the pattern of Chernobyl deposition and the range in concentrations over the country, and to establish a baseline for subsequent assessment of the movement and distribution of radionuclides deposited in the terrestrial environment. Representative samples of vegetation needed to be collected quickly before the concentrations of radionuclides were affected by weathering, plant uptake or grazing by animals.

The wide geographical spread of the ITE research stations enabled samples to be collected simultaneously over most of 
Table 1. A description of the data included in this paper.

\begin{tabular}{|c|c|c|c|c|c|}
\hline $\begin{array}{l}\text { Data } \\
\text { set ID }\end{array}$ & Years & What was sampled? & Radionuclides reported & Other parameters reported & Number of samples \\
\hline 1 & $\begin{array}{l}1986 \\
1987\end{array}$ & $\begin{array}{l}\text { Vegetation, (grass, heather, bracken) } \\
\text { soil and wildlife (game birds, hare } \\
\text { species, fox, rabbit and red deer) }\end{array}$ & $\begin{array}{l}\text { Cs-137, Cs-134, Ru-106, } \\
\text { Ru-103, K-40 }\end{array}$ & $\begin{array}{l}\text { Soil } \mathrm{pH} \text {, depth, LOI*, texture and } \\
\text { wet and dry weight of vegetation }\end{array}$ & 1585 \\
\hline 2 & $\begin{array}{l}1986 \\
1987 \\
1988\end{array}$ & Vegetation (grass and heather) & Cs-137, Cs-134 & Soil type, pH, ITE Land Class & 381 \\
\hline 3 & $\begin{array}{l}1989 \\
1990\end{array}$ & Soil $(0-4$ and $>4 \mathrm{~cm})$ and vegetation & $\begin{array}{l}\text { Cs-137, Cs-134, K-40, } \\
\text { Pu-238, Pu-239, Pu-240 }\end{array}$ & Soil depth and bulk density & 168 \\
\hline 4 & 1992 & Soil $(0-4$ and $>4 \mathrm{~cm})$ and vegetation & Cs-137, Cs-134 & $\begin{array}{l}\text { Soil type, bulk density, depth, } \mathrm{pH} \text {, } \\
\mathrm{LOI}^{*}, \mathrm{~K} \text { and } \mathrm{NH}_{4} \text { and vegetation } \\
\text { group (determined by TWINSPAN } \\
\text { analysis) and weight. }\end{array}$ & 258 \\
\hline 5 & $\begin{array}{l}1995 \\
1995 \\
1996 \\
1987\end{array}$ & $\begin{array}{l}\text { Fungi ( } 37 \text { species) and soil (organic and } \\
\text { mineral layers) }\end{array}$ & Cs-137, Cs-134 & Soil depth and bulk density. & 423 \\
\hline
\end{tabular}

Great Britain (GB) by trained fieldworkers. A stratified sampling scheme was used based on the ITE Land Classification of Great Britain (Bunce et al., 1981; Benefield and Bunce, 1982). This classification used climatic, topographic, geological and land use characteristics to define 1 kilometre squared $\left(\mathrm{km}^{2}\right)$ land units; multivariate analysis techniques were used to develop a classification describing Great Britain in terms of 32 land classes (Bunce et al., 1981; Benefield and Bunce, 1982). To respond swiftly to the Chernobyl accident, the classification was simplified (using Indicator Species Analysis) to result in 16 land class groups (Horrill and Lindley, 1990). Twenty one-kilometre square areas for each class were randomly selected, resulting in 320 sampling sites being chosen as representative of the main variation in land classes within Great Britain. Grassy or graminaceous vegetation (including sedges and rushes), was sampled by the field surveyors. Graminaceous vegetation samples were in part chosen due to the fact that these plants form an important component of the food of grazing animals. Sample sites were selected to be away from roadsides (to avoid splash) and overhanging vegetation (to avoid throughfall from trees). 318 sites were sampled in total; 2 sites had to be omitted for practical reasons. These data were used to produce the first spatial visualisation of Chernobyl fallout over mainland Great Britain (Allen, 1986; Fig. 2).

The initial survey was repeated in October 1986 and extended to include upper and lower soil horizons and other vegetation types (heather (Calluna vulgaris) and bracken (Pteridium aquilinum)) (Horrill et al., 1988). In addition to vegetation, samples of wildlife - rabbit (Oryctolagus cuniculus), hare (Lepus capensis and Lepus timidus), fox (Vulpes vulpes), red deer (Cervus elaphus), woodcock (Scolopex rusticola) and grouse (Tetrao tetrix and Lagopus lagopus) were collected and analysed to assess the uptake of radioactivity by wild herbivores and carnivores. Samples of food in-

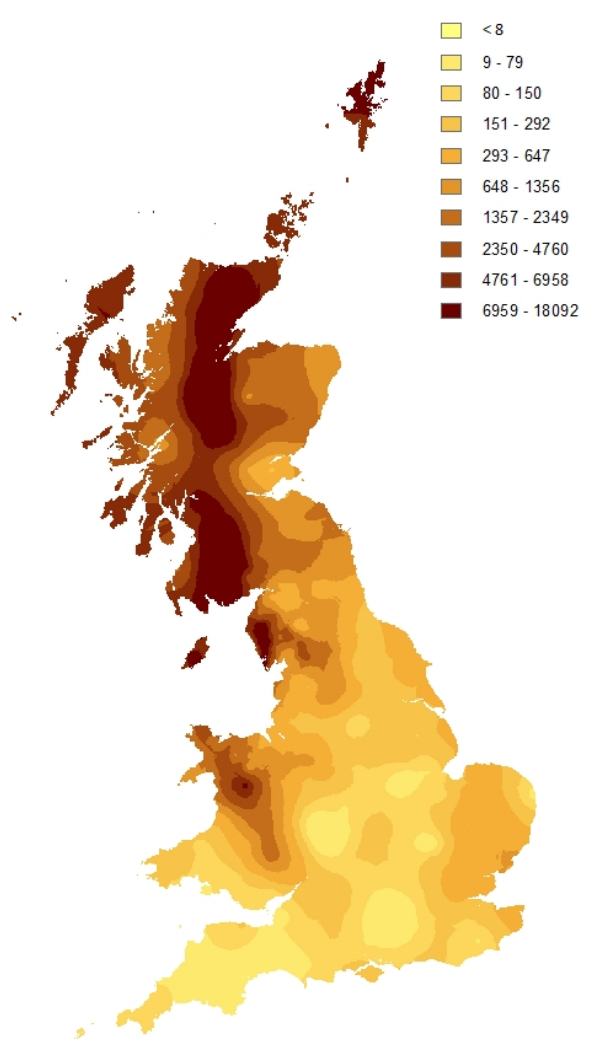

Figure 2. Spatial visualisation of Chernobyl fallout over Great Britain in May 1986 (137Cs activity concentrations in graminaceous vegetation $\left(\mathrm{Bq} \mathrm{kg}^{-1}\right.$ Dry Matter (DM)).

gested shortly before death were also obtained by collecting rumen, stomach and crop contents from the various species. One hundred and forty-six determinations of animal tissue were made and 94 samples of gastrointestinal tract contents were analysed. 
In spring 1987, a survey was carried out to re-analyse the 100 areas in Scotland with the highest concentrations of ${ }^{137} \mathrm{Cs}$ in vegetation as determined in May/June 1986. A further 56 sites in the western Isles of Scotland that had not been included in the earlier surveys were also sampled.

For all surveys, vegetation was sampled by clipping from a 1 metre squared $\left(\mathrm{m}^{2}\right)$ using garden shears to within $1 \mathrm{~cm}$ of the soil surface. Plant material was oven dried at $85^{\circ} \mathrm{C}$ for $24 \mathrm{~h}$, the total mass per metre square was recorded, ground (Christy and Norris mill using a $0.7 \mathrm{~mm}$ sieve) and 40 to $50 \mathrm{~g}$ material accurately weighed into $150 \mathrm{~mL}$ sample containers.

Soil was sampled by taking a $20 \times 20 \times 15 \mathrm{~cm}$ layer from the centre of the vegetation sampling plot. If a litter layer was present this was removed and stored as a separate sample. Where an obvious soil horizon was present the soil block was divided and the dimensions of each subsample were recorded. Fresh soil $\mathrm{pH}$ was measured and soil texture was assessed in terms of clay, silt, sand and organic matter. The soil was broken up by hand, oven dried at $60^{\circ} \mathrm{C}$ for $24-36 \mathrm{~h}$, sieved and separated into greater and less than $(<) 2 \mathrm{~mm}$ fractions. Gamma spectrometry was carried out on the $<2 \mathrm{~mm}$ fraction. Samples were retained in a cold store at approximately $2{ }^{\circ} \mathrm{C}$ until processed.

Sampling of animals and birds relied heavily on the cooperation and goodwill of landowners, stalkers, gamekeepers and Forestry Commission Rangers. Samples of flesh were removed from the necks of deer, legs and backs of hares, rabbits and foxes and from the breast of the bird species. Gastrointestinal tract contents were retained. Samples were weighed and frozen prior to analysis. Samples were thawed for $24 \mathrm{~h}$ prior to gamma analysis.

Radiocaesium levels were determined as activity concentrations per unit dry matter (DM) of vegetation or soil and deposition per unit area, by high resolution gamma spectroscopy using either hyperpure germanium or germaniumlithium detectors with relative efficiencies of $20-25 \%$ for between 25000 to $80000 \mathrm{~s}$ to achieve a counting error of $<5 \%$ (at 1.65 sigma). Detectors were calibrated using British Calibration Service standards incorporated into appropriate matrices (including different soil densities) and volumes. Accuracy was checked against international standards (Horrill et al., 1988). The unit of activity reported, for this and subsequent data sets, was the bequerel $(\mathrm{Bq})$ which equates to 1 disintegration per second. All results were decay corrected to the date of sampling. Animal samples reported on a fresh weight basis with the exception of gastrointestinal tract samples which were dried prior to analysis. An evaluation of factors such as weighing of sample, analyst, positioning on detector head, etc. demonstrate that the counting error (which includes errors for the standard and radionuclide decay) dominates the total error.

\subsubsection{Data set 2}

In May/June 1987 graminaceous vegetation was collected from 26 sites in and around the area of North Wales where restrictions were in place on the movement and slaughter of sheep (Beresford et al., 1987a) and 70 sites in and around the restricted area of west Cumbria (Beresford et al., 1987b). Sampling sites were those used in the initial GB survey conducted in 1986 as outlined above. Collection and sample preparation was as described above for the GB wide surveys. Samples were analysed using a lead-shielded 3 inch (") sodium iodide activated with thallium ( $\mathrm{NaI}(\mathrm{Tl}))$ detector with a sub-set of samples being reanalysed using germanium $(\mathrm{Ge})$ detectors. Soils from each sampling site were categorised on the basis of textural class (i.e. clay, silt, sand, loam or organic) and soil $\mathrm{pH}$ determined using the method of Allen (1989). Previously unreported in the open literature, these surveys demonstrated that those sampling sites at which radiocaesium levels had decreased the least had organic soils.

Smith (1996) suggested that areas of North Yorkshire received high rainfall during the passage of the Chernobyl cloud and it was therefore suggested that the area may have received relatively high levels of deposition. Two hundred and fifty-six sites were sampled in January 1988 (Howard et al., 1988). In addition to graminaceous vegetation, new growth Calluna vulgaris (heather) was also sampled if present. Heather was collected from 45 of the sampling sites; from 7 sites no graminaceous species were present and only heather was sampled. Samples were prepared as above and initially analysed using a lead-shielded $3^{\prime \prime} \mathrm{NaI}(\mathrm{Tl})$ detector to determine ${ }^{137} \mathrm{Cs}$ activity concentrations. Those grass samples with detectable $\left(>340 \mathrm{~Bq} \mathrm{~kg}^{-1}\right.$ ) levels of ${ }^{137} \mathrm{Cs}$ were then reanalysed using Ge-detectors to determine ${ }^{134} \mathrm{Cs}$ and ${ }^{137} \mathrm{Cs}$ activity concentrations; all heather samples were analysed using Ge-detectors. Only 9 grass samples had activity concentrations in excess of $340 \mathrm{~Bq} \mathrm{~kg}^{-1} \mathrm{DM}$. Activity concentrations in heather were higher than those in grass with a maximum of $650 \mathrm{~Bq}^{134} \mathrm{Cs} \mathrm{kg}^{-1}$ and $3300 \mathrm{~Bq}{ }^{137} \mathrm{Cs} \mathrm{kg}^{-1}$ being recorded. From the ${ }^{134} \mathrm{Cs}:{ }^{137} \mathrm{Cs}$ ratio it was evident that a significant proportion of the ${ }^{137} \mathrm{Cs}$ in some samples originated from sources other than the Chernobyl accident (i.e. predominantly above grounds nuclear weapons testing fallout) (Beresford et al., 1992). A sigmoidal relationship was derived between reported rainfall (extracted from Meteorological Rainfall data see Howard et al., 1988) and the ${ }^{134} \mathrm{Cs}:{ }^{137} \mathrm{Cs}$ ratio in North Yorkshire heather samples $\left(r^{2}=\right.$ $0.7)$.

${ }^{134} \mathrm{Cs}:{ }^{137} \mathrm{Cs}=\frac{0.3}{1+1.26 \times \text { rainfall }^{-0.71}}$

\subsubsection{Data set 3}

A helicopter survey of radiocaesium deposition identified areas with unexpected ${ }^{137} \mathrm{Cs}:{ }^{134} \mathrm{Cs}$ ratios in Cumbria in July 
and August 1988 (Sanderson and Scott, 1989). A ground survey of radiocaesium activity concentrations in soils was conducted in three areas (each $3 \times 5 \mathrm{~km}$ ) in the south western corner of the restricted area of west Cumbria in 1989 and 1990, to compare with the aerial survey results (Beresford et al., 1990). The areas were predominantly unimproved grassland (fell) with some enclosed pastures, woodland or areas of heather (Calluna vulgaris). Thirty-six samples of soil (down to a maximum of $40 \mathrm{~cm}$ depth) were collected from each area. Soil bulk density was determined for the complete profile by weighing a known volume of soil. In two of the areas additional sampling was conducted to study radiocaesium uptake by vegetation (Beresford et al., 1990, 1992). Vegetation was clipped to the level of plant bases from an area of $1 \mathrm{~m}^{2}$. Samples of soil were taken to a depth of $40 \mathrm{~cm}$ or bedrock if the soil was shallower than $40 \mathrm{~cm}$. The $0-4 \mathrm{~cm}$ layer was separated from the rest of the profile. Soil and vegetation samples were weighed fresh, dried at $80^{\circ} \mathrm{C}$ and then reweighed to determine moisture content. Bulk density was measured for both soil layers by drying and weighing a known volume of soil. Samples were then ground and weighed into plastic containers $(150 \mathrm{~mL})$ or Marinelli beakers $(750 \mathrm{~mL})$ for gamma analyses using high-resolution Ge-detectors. Count times ranged from 40000 to $170000 \mathrm{~s}$ depending upon the radioactivity present to give a counting error of $<5 \%$ (95\% confidence level; note an evaluation of factors such as weighing of sample, analyst, positioning on detector head, etc. demonstrate that the counting error (which includes errors for the standard and radionuclide decay) dominates the total error. The detectors were calibrated using mixed gamma standards (National Physical Laboratory, Teddington, UK). In the areas studied, aged radiocaesium, primarily from nuclear weapons fallout and the 1957 Windscale accident, accounted for $30-60 \%$ of the ${ }^{137} \mathrm{Cs}$ deposit (Beresford et al., 1990). The uptake by graminaceous vegetation was found to be similar for both aged and Chernobyl radiocaesium (differentiated using the ${ }^{134} \mathrm{Cs}:{ }^{137} \mathrm{Cs}$ ratio) (reported in Beresford et al., 1992).

For a subset of the samples ${ }^{238} \mathrm{Pu}$ and ${ }^{239,240} \mathrm{Pu}$ activity concentrations were determined in vegetation and soils following the radiochemical extraction and the alpha counting procedure as described by Livens and Singleton (1991). For completeness these data are presented in the database; they have previously not been reported and there are few measurements of these isotopes in upland ecosystems in Cumbria.

\subsubsection{Data set 4}

Beresford et al. (1996, 1998, 2000, 2007) describe a series of studies conducted at three upland sheep farms in west Cumbria to investigate the reasons for variability in the radiocaesium activity concentration in sheep within an individual flock. To support this work, samples of soil and graminaceous vegetation were collected during the summer of 1992 (Beresford et al., 2007). The farm codes (A, B and C) used here are consistent with those used in previous publications (Beresford et al., 1996, 2000) and the accompanying data set (Chaplow et al., 2015).

Eighty sites selected randomly from a $100 \mathrm{~m}$ grid based on Ordnance Survey national grid squares were sampled over the grazing areas of each of Farms A and C (both circa $3 \mathrm{~km}^{2}$ ); whereas, over the larger $\left(\mathrm{ca} .7 \mathrm{~km}^{2}\right)$ grazing area of Farm B, 100 randomly selected sites were sampled.

Soil maps (1:25000 scale) were produced by soil surveyors using soil augers and small pits along a transect (Beresford et al., 2007). Data from transects were extrapolated to the rest of the sampling area using aerial photographs (ADAS $1: 10000$ and $1: 18000$ scale). Soils were classified according to Avery (1980). Soil samples were collected to a depth of $30 \mathrm{~cm}$ or bedrock/stone layer using a spade, trimmed and divided into two layers, $0-4$ and $>4 \mathrm{~cm}$. Vegetation was collected from a known area to a height of ca. $1 \mathrm{~cm}$ above the ground surface using hand shears.

Soil and vegetation were dried at $80^{\circ} \mathrm{C}$, weights were recorded and samples were ground. Soil bulk density and loss on ignition (LOI) were determined as described above. The ${ }^{134} \mathrm{Cs}$ and ${ }^{137} \mathrm{Cs}$ activity concentrations in soil and vegetation samples were determined using hyper-pure Ge-detectors with relative efficiencies ranging from 25 to $40 \%$. Resultant spectra were analysed using the Canberra Apogee software package; analysis times (ranging from 5000 to $60000 \mathrm{~s}$ depending upon sample activity) were sufficient to achieve a counting error of less than $5 \%$ of the reported result for ${ }^{137} \mathrm{Cs}$ at 1.65 sigma. The detectors were calibrated using mixed gamma standards (National Physical Laboratory).

\subsubsection{Data set 5}

This data set contains information from two studies. In the first study samples of the most frequently eaten (as identified in a survey by Barnett et al., 1999) autumn and spring fruiting fungi species were sampled throughout Great Britain between spring 1995 and spring 1996 to assess radiocaesium contamination levels and geographical variation (Barnett et al., 1999). The data set contains information from fruiting species where, in most cases, soil samples were also collected from the same location as the fruiting bodies. In the second study, further samples were collected as part of the European Commission (EC) SAVE project (No. F14PCT950015) in autumn 1997 and spring 1998; species targeted were spring fruiting and those that had showed higher levels of ${ }^{137} \mathrm{Cs}$ accumulation in the Barnett et al. (1999) study.

From each site approximately $200 \mathrm{~g}$ fresh weight (FW) of fruiting bodies (425 samples representing 37 different species) were sampled. Soil samples were taken from beneath the fruiting body using a metal soil corer with a diameter of $61 \mathrm{~mm}$ and of either 100 or $200 \mathrm{~mm}$ in length, depending upon the anticipated total soil depth. The litter layer, if present, was included within the soil sample. 
The fruiting bodies were weighed and dried at $60^{\circ} \mathrm{C}$ to a constant weight. The dried samples were then ground in a small mill and the ground material transferred to plastic containers of a suitable size (between 10 and $150 \mathrm{~mL}$ ) prior to gamma analysis. The soil samples were carefully removed from the corers and visually divided into an organic layer (including the litter layer, if present) and mineral layer. Each portion of the soil was dried at $60^{\circ} \mathrm{C}$ to a constant weight and the bulk density determined. The dried soil samples were then ground in a ball mill before being weighed into suitably sized containers (between 10 and $700 \mathrm{~mL}$ ) for subsequent gamma analyses.

Samples were analysed on hyper-pure germanium detectors calibrated using mixed gamma standards (National Physics Laboratory) using the Canberra APOGEE or PROCOUNT software packages to determine the activity concentration of gamma-emitting radionuclides. Analyses times ranged from 1500 to $240000 \mathrm{~s}$ depending upon the activity present. Results were decay corrected to the date of sampling and where possible, a counting error of less than $5 \%$ (at 1.65 sigma) of the result for ${ }^{137} \mathrm{Cs}$ was achieved.

\section{Access and conditions of use}

The data described here have a Digital Object Identifier doi:10.5285/d0a6a8bf-68f0-4935-8b43-4e597c3bf251 and are freely available from the CEH Environmental Information Data Centre (http://eidc.ceh.ac.uk/) under the Open Government Licence. These must be referenced fully for every use of the data as: Chaplow, J. S., Beresford, N. A., and Barnett, C. L. (2015): Post Chernobyl surveys of radiocaesium in soil, vegetation, wildlife and fungi in Great Britain. NERC-Environmental Information Data Centre doi:10.5285/d0a6a8bf-68f0-4935-8b43$4 \mathrm{e} 597 \mathrm{c} 3 \mathrm{bf} 251$ and where appropriate the source references as cited above. Supporting information to aid in the reuse of this data is available from the EIDC.

Acknowledgements. This paper and preparation of the associated database were supported by the Centre for Ecology and Hydrology and the EC EURATOM Network of Excellence STAR (http://www.star-radioecology.org/). The original project work carried out in the 1980s and 1990s was funded by the Natural Environment Research Council, the Ministry of Agriculture Fisheries and Food, EC SAVE project (No. F14PCT950015), the Department of the Environment and the Scottish Development Department.

Edited by: D. Carlson

\section{References}

Allen, S. E.: Radiation: A guide to a contaminated countryside, The Guardian, 25 July, p. 17, 1986.

Allen, S. E.: Chemical Analysis of Ecological Materials, Blackwell Scientific Publications, London, 368 pp., 1989.

Avery, B. W.: Soil classification for England and Wales (higher categories), Soil Survey Technical Monograph No. 14, Soil Survey: Harpenden, 1980.

Barnett, C. L., Beresford, N. A., Self, P. L., Howard, B. J., Frankland, J. C., Fulker, M. J., Dodd, B. A., and Marriott, J. V. R.: Radiocaesium activity concentrations in the fruit-bodies of macrofungi in Great Britain and an assessment of dietary intake habits, Sci. Total Environ., 231, 67-83, doi:10.1016/S00489697(99)00085-6, 1999.

Benefield, C. B. and Bunce, R. G. H.: A preliminary visual presentation of land classes in Britain, NERC, Institute of Terrestrial Ecology, 39 pp., Merlewood Research and Development Paper No. 91, available at: http://nora.nerc.ac.uk/6851/ (last access: 18 August 2015), 1982.

Beresford, N. A., Adamson, J. K., and Howard, B. J.: A comparison of 1986 and 1987 caesium activities of vegetation in west Cumbria, Final Report MAFF/NERC, Institute of Terrestrial Ecology, 16 pp., ITE Project No: ITE1113, available at: http: //nora.nerc.ac.uk/508148/ (last access: 18 August 2015), 1987a.

Beresford, N. A., Howson, G., and Adamson, J. K.: A comparison of 1986 and 1987 caesium activities of vegetation in the restricted area of North Wales, Final report, NERC/Institute of Terrestrial Ecology, 12 pp., ITE Project No: ITE1113), available at: http: //nora.nerc.ac.uk/501174 (last access: 18 August 2015), 1987b.

Beresford, N. A., Barnett, C. L., Howard, B. J., Poskitt, J., and Dighton, J.: Vegetation and Soil Survey in Cumbria to Validate the Aerial Survey of 1988, Final report, TFS Project T07051e1, 52 pp., Ministry of Agriculture, Fisheries and Food, available at: http://nora.nerc.ac.uk/id/eprint/507836 (last access: $18 \mathrm{Au}-$ gust 2015), 1990.

Beresford, N. A., Howard, B. J., Barnett, C. L., and Crout, N. M. J.: The uptake by vegetation of Chernobyl and aged radiocaesium in upland West Cumbria, J. Environ. Radioact., 16, 181195, doi:10.1016/0265-931X(92)90015-L, 1992.

Beresford, N. A., Barnett, C. L., Crout, N. M. J., and Morris, C. C.: Radiocaesium variability within sheep flocks: relationships between the ${ }^{137} \mathrm{Cs}$ activity concentrations of individual ewes within a flock and between ewes and their progeny, Sci. Total Environ., 177, 85-96, doi:10.1016/0048-9697(95)04863-4, 1996.

Beresford, N. A., Mayes, R. W., Barnett, C. L., MacEachern, P. J., and Crout, N. M. J.: Variation in the metabolism of radiocaesium between individual sheep, Radiat. Environ. Bioph., 37, 277-281, doi:10.1007/s004110050129, 1998.

Beresford, N. A., Barnett, C. L., and Mayes, R. W.: Radiocaesium variability within sheep flocks: determination of ${ }^{137} \mathrm{Cs}$ intake in free-ranging sheep, Radiat. Environ. Bioph., 39, 207-212, doi:10.1007/s004110000064, 2000.

Beresford, N. A., Barnett, C. L., Wright, S. M., Howard, B. J., and Crout, N. M. J.: Factors contributing to radiocaesium variability in upland sheep flocks in west Cumbria (United Kingdom), J. Environ. Radioact., 98, 50-68, doi:10.1016/j.jenvrad.2007.05.009, 2007. 
Beresford, N. A., Barnett, C. L., Howard, B. J., Howard, D. C., Wells, C., Tyler, A. N., Bradley, S., and Copplestone, D.: Observations of Fukushima fallout in Great Britain, J. Environ. Radioact., 114, 48-53, doi:10.1016/j.jenvrad.2011.12.008, 2012.

Bunce, R. G. H., Barr, C. J., and Whittaker, H. A.: Land classes in Great Britain: preliminary descriptions for users of the Merlewood method of land classification, NERC/Institute of Terrestrial Ecology, 54 pp., Merlewood Research and Development Paper, 86, available at: http://nora.nerc.ac.uk/5898 (last access: 18 August 2015), 1981.

Chaplow, J. S., Beresford, N. A., and Barnett, C. L.: Post Chernobyl surveys of radiocaesium in soil, vegetation, wildlife and fungi in Great Britain, NERC-Environmental Information Data Centre, doi:10.5285/d0a6a8bf-68f0-4935-8b43-4e597c3bf251, 2015.

De Cort, M., Dubois, G., Fridman, Sh. D., Germenchuk, M. G., Izrael, Yu. A., Janssens, A., Jones, A. R., Kelly, G. N., Kvasnikova, E. V., Matveenko, I., Nazarov, I. M., Pokumeiko, Yu. M., Sitak, V. A., Stukin, E. D., Tabachny, L. Ya., Tsaturov, Yu. S., and Avdyushin, S. I.: Atlas of caesium deposition on Europe after the Chernobyl accident, Luxembourg, Office for Official Publications of the European Communities, ISBN 92-828-3140-X, Catalogue number CG-NA-16-733-29-C, EUR 16733, 1-63, 1998.

Environment Agency: Food Standards Agency, Northern Ireland Environment Agency and Scottish Environment Protection Agency: Radiation in food and the Environment, 2012 (RIFE 18), available at: http://www.sepa.org.uk/environment/radioactive-substances/ environmental-monitoring-and-assessment/reports/ (last access: 18 August 2015), 2013.

Gillett, A. G., Crout, N. M. J., Absalom, J. P., Wright, S. M., Young, S. D., Howard, B. J., Barnett, C. L., McGrath, S. P., Beresford, N. A., and Voigt, G.: Temporal and spatial prediction of radiocaesium transfer to food products, Radiat. Environ. Bioph., 40, 227-235, doi:10.1007/s004110100107, 2001.

Hinton, T. G., Garnier-Laplace, J., Vandenhove, H., Dowdall, M., Adam-Guillermin, C., Alonzo, F., Barnett, C., Beaugelin-Seiller, K., Beresford, N. A., Bradshaw, C., Brown, J., Eyrolle, F., Fevrier, L., Gariel, J.-C., Gilbin, R., Hertel-Aas, T., Horemans, N., Howard, B. J., Ikäheimonen, T., Mora, J. C., Oughton, D., Real, A., Salbu, B., Simon-Cornu, M., Steiner, M., Sweeck, L., and Vives i Batlle, J.: An invitation to contribute to a strategic research agenda in radioecology, Environ. Radioactivity, 115, 7382, doi:10.1016/j.jenvrad.2012.07.011, 2013.
Horrill, A. D. and Lindley, D. K.: Monitoring method based on land classification for assessing the distribution of environmental contamination, in: Proc. Int. Symp. on Environmental Contamination Following a Major Nuclear Accident, FAO/IAEA/UNEP/WHO, Vienna, 16-20 October 1989, IAEASM-306/43, 205-213, Elsevier Applied Science: London, 1990.

Horrill, A. D., Lowe, V. W., and Howson, G.: Chernobyl Fallout in Great Britain, Final report, 94 pp., TFS Project T07006e1, Department of the Environment, available at: http://nora.nerc.ac.uk/ id/eprint/501172 (last access: 16 May 2014), 1988.

Howard, B. J. and Beresford, N. A.: Chernobyl radiocaesium in an upland sheep farm ecosystem, Brit. Vet. J., 145, 212-219, doi:10.1016/0007-1935(89)90073-0, 1989.

Howard, B. J., Beresford, N. A., and Nelson, W. A.: ${ }^{134}$ Cs and ${ }^{137}$ Cs activity in vegetation of North Yorkshire in January 1988, TFS Project T07007C1, MAFF Project N494, NERC/ Institute of Terrestrial Ecology report for Ministry of Agriculture, Fisheries and Food, available at: http://nora.nerc.ac.uk/id/eprint/507843 (last access: 18 August 2015), 1988.

Livens, F. R. and Singleton, D. L.: Plutonium and americium in soil organic matter, J. Environ. Radioact., 13, 323-339, doi:10.1016/0265-931X(91)90005-Z, 1991

Sanderson, D. C. W. and Scott, E. M.: Aerial Radiometric Survey in West Cumbria 1988, Final Report: Project N611, Project Report, Scottish Universities Research and Reactor Centre, Glasgow, UK, available at: http://eprints.gla.ac.uk/57332/ (last access: 18 August 2015), 1989.

Smith, F. B.: Chernobyl - the radioactive plume and its consequences, Bracknell: Meteorological Office, 48 pp., 1996.

Smith, F. B. and Clark, M. J.: The transport and deposition of airborne debris from the Chernobyl Nuclear Power Plant accident, with special emphasis on the consequences to the U.K. Meteorological Office, Scientific paper No. 42HMSO, P.O. Box 276, London, SW8 5DT, 1989.

Smith, J. T. and Beresford, N. A.: Radioactive fallout and environmental transfers, in: Chernobyl - catastrophe and consequences, edited by: Smith, J. T. and Beresford, N. A., Chichester, Praxis Publishing/Springer, 35-80, 2005.

Wright, S. M., Smith, J. T., Beresford, N. A., and Scott, W. A.: Monte-Carlo prediction of changes in areas of west Cumbria requiring restrictions on sheep following the Chernobyl accident, Radiat. Environ. Bioph., 42, 41-47, doi:10.1007/s00411003-0187-6, 2003. 